\title{
Differential ion-selective membrane electrode-based potentiometric gas-sensing cells with enhanced gas sensitivity
}

\author{
Hyoung Sik Yim, Geun Sig Cha and Mark E. Meyerhoff * \\ Department of Chemistry, University of Michigan, Ann Arbor, MI 48109 (U.S.A.)
}

(Received 27th December 1989)

\begin{abstract}
A novel design for devising static and automated flow-through type potentiometric gas-sensing systems with enhanced response slopes is described. The approach involves the use of two working gas-sensing electrode half-cells in a differential measurement arrangement. One of the half-cells employs a $\mathrm{pH}$-sensitive polymeric membrane electrode to sense $\mathrm{pH}$ changes from diffusing analyte gas within a suitable inner electrolyte solution housed behind an outer gas-permeable membrane. The second working half-cell is fabricated with an anion- or cation-selective membrane electrode that responds selectively to the conjugate acid or base ionic form of the analyte gas trapped within an inner buffer solution housed behind a similar gas-permeable membrane. When the two internal solutions of the half-cells are in electrolytic contact, the differential response of the resulting gas-sensing scheme is significantly enhanced compared with the response of a conventional single working electrode/reference electrode type gas cell. For the model analyte gas ammonia, response slopes observed for both static and flow-through measurement schemes approach the $118 \mathrm{mV}$ decade ${ }^{1}$ predicted by theory. To demonstrate its analytical utility, the flow-through arrangement was used to determine ammonia- $\mathrm{N}$ concentrations in bioreactor media with good correlation with conventional electrode and enzymatic methods. The prospects of fabricating similar differential detection arrangements for $\mathrm{CO}_{2}, \mathrm{NO}_{2}$ and $\mathrm{SO}_{2}$ are discussed.
\end{abstract}

Keywords: Ion-selective electrodes; Ammonia; Nitrogen

Over the past two decades, potentiomeric gassensing devices have proved to be attractive analytical tools for the direct detection of dissolved gases (e.g., $\mathrm{NH}_{3}, \mathrm{CO}_{2}, \mathrm{NO}_{2}$ ) in complex samples, including whole blood [1-4]. In addition, when used in conjunction with immobilized enzymes and intact cells, these gas sensors can provide a simple indirect means of quantitating a wide range of biomolecules via modern biosensing configurations [5-7]. Whereas commercial gas sensors often used in these applications employ glass membrane $\mathrm{pH}$ electrodes as inner transducers in a so-called Severinghaus detection arrangement [8], the ad- vantages of using polymetric $\mathrm{pH}$ sensors in an analogous measurement mode has been demonstrated previously [9]. In addition, the use of internal polymeric ion-selective membrane electrodes responsive to ionic forms of the analyte gases (e.g., $\mathrm{NH}_{4}^{+}, \mathrm{SO}_{3}^{2-}, \mathrm{CO}_{3}^{2-}$, and $\mathrm{NO}_{3}^{-}$) to devise both static and automated flow-through potentiometric gas detectors with improved selectivity and detection limits has been described [10-16]. In more recent preliminary studies [17], it has been shown that these two different approaches to gas detection can be combined in a single differential potentiometric measurement cell to yield gas 
sensor designs with significantly enhanced response sensitivities (as defined by the change in analytical signal/change in concentration, i.e., response slope). The purpose of this paper is to provide a more detailed description of the general operating principles of this type of differential detection scheme, and to illustrate the adaptation of this new approach to a flow-through measurement arrangement with an analytically useful performance.

As with any electrochemical detector used in a direct potentiometric measurement mode of analysis (i.e., non-titration method), conventional Severinghaus-style gas sensors and the newer polymer membrane-based devices cited above are subject to precision limitations associated with the logarithmic response of such devices. Indeed, uncertainties in measured potentials of $\pm 1 \mathrm{mV}$ will result in deviations of $\pm 4 \%$ for sensors with slopes of $59 \mathrm{mV}$ decade $^{-1}$ and $\pm 8 \%$ for those devices based on response to divalent ions (e.g., based on inner sulfite and carbonate electrodes). One general approach suggested for enhancing the response slopes of potentiometric sensors is to use several membrane electrode based cells in series [18]. This arrangement results in response slopes $n$ times the Nernstian value, where $n$ is the number of two-electrode cells (working and reference) in series. Unfortunately, this approach requires a complicated array of sensors where the number of individual electrodes needed is increased, as is the number of separate sample compartments.

Alternatively, Cha and Meyerhoff [15] described a novel two-electrode differential potentiometric cell for enzyme electrode systems that provides enhanced substrate sensitivities when compared with conventional cells composed of a single working enzyme electrode and reference electrode. This concept involves the use of a cell with two working enzyme electrodes, one of which responds to the analyte in the positive potential direction via detection of cations, the other responding to the same analyte but in a negative detection owing to anion detection. As described here, a similar approach can also be adapted for the design of new two-electrode gas-selective sensors with enhanced sensitivity to gases. Specifically, this concept is demonstrated by describing the perfor- mance of new static and flow-through ammoniaselective gas-sensing systems with analytical response slopes approaching $118 \mathrm{mV}$ decade $^{-1}$.

\section{THEORY}

The proposed differential gas-sensing system is composed of two working gas probes, each with a different inner polymeric ion-selective membrane electrode as the transducer. For static configurations, this involves the use of two different gassensing half-cell probes where the internal filling solutions are connected via a salt bridge (see Fig. 1). The overall notation for this type of electrochemical cell is shown as follows:

(2)

pH electrode | internal electrolyte |internal buffer |

membrane electrode sensitive to conjugate ion

One half-cell (2) responds to the basic or acidic analyte gas by detecting an increase or decrease in the $\mathrm{pH}$ of a thin film of electrolyte (e.g., ammonium chloride for an ammonia gas sensor) sandwiched between a $\mathrm{pH}$-sensitive membrane (prepared with tridodecylamine as membrane active species [9]) and an outer gas-permeable membrane. The second half-cell (1) detects the analyte gas in the sample by responding to changes in the activities of the conjugate base anion or acid cation of the analyte gas in a thin layer of buffer sandwiched between an ion-selective membrane and another outer gas-permeable film.

Accordingly, the overall measured potential for such a two-working-electrode cell is the difference in potential between the ion-selective electrode and the $\mathrm{pH}$ electrode:

$E_{\text {cell }}=E_{\text {conj.ion }}-E_{\mathrm{pH}}$

or

$E_{\text {cell }}=K+\left(0.059 / z_{i}\right) \log a_{\text {conj.ion }}-0.059 \log a_{\mathrm{H}^{+}}$

where $a_{\text {conj.ion }}\left(a_{\mathrm{BH}^{z^{+}}}\right.$or $\left.a_{\mathrm{A}^{-}}\right)$and $a_{\mathrm{H}^{+}}$are the activities of the conjugate ions of analyte gas and protons in the thin films of internal solutions held between the outer gas-permeable membranes and the respective ion-selective membranes, and $K$ is the sum of all constant potentials in the cell (e.g., 


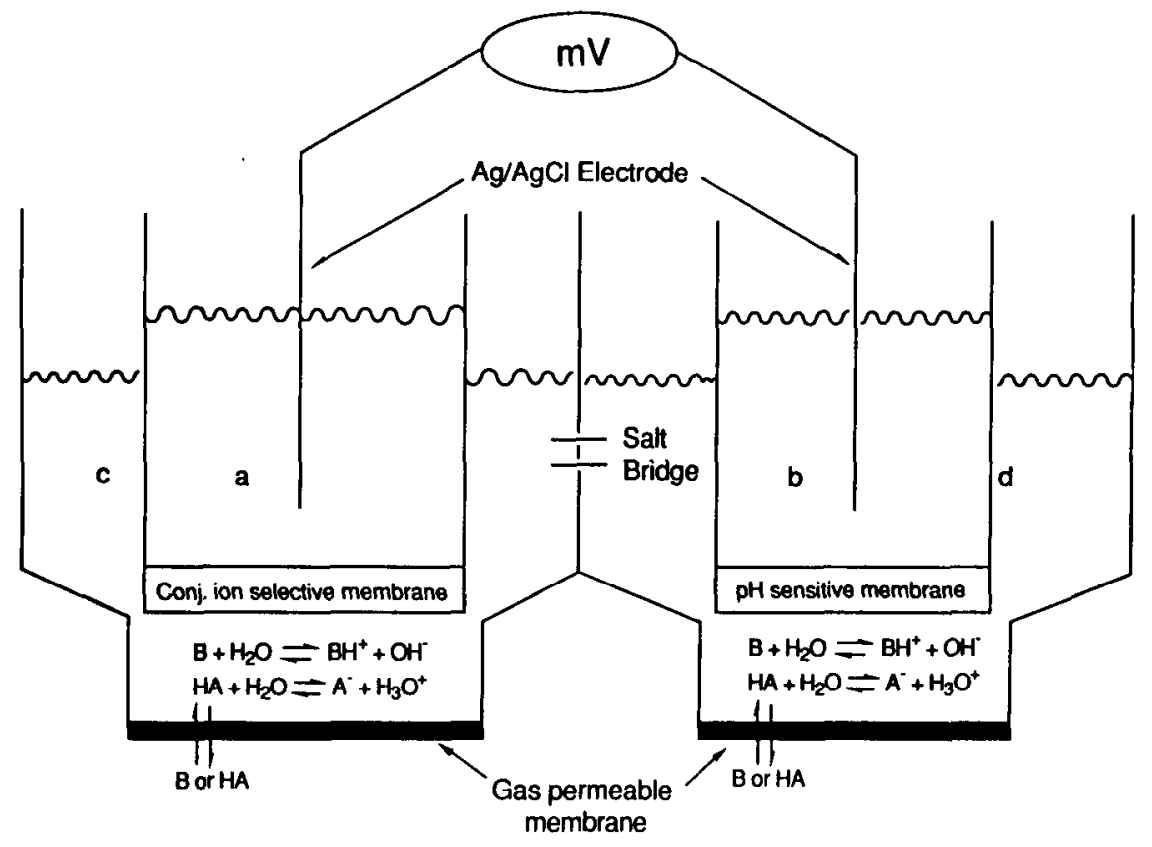

Fig. 1. Schematic diagram of differential gas sensor fabricated with two different polymeric ion-selective membranes: (a) $0.1 \mathrm{M} \mathrm{BHCl}$ or $\mathrm{MA}+\mathrm{NaCl}$; (b) $0.1 \mathrm{M}$ phosphate buffer ( $\mathrm{pH} 7.0$ ) containing $0.1 \mathrm{M} \mathrm{NaCl}$; (c) buffered internal solution such as $0.1 \mathrm{M}$ Tris- $\mathrm{HCl}$ (pH 7.9) for ammonia sensor; (d) pH-sensing internal electrolyte solution (see Table 1).

junction potentials at salt bridge, inner $\mathrm{Ag} / \mathrm{AgCl}$ potentials of each membrane electrode). Diffusion of the basic or acidic analyte gas into the thin films results in the equilibrium hydrolysis reaction of the analyte gas:

$\mathrm{B}+\mathrm{H}_{2} \mathrm{O}=\mathrm{BH}^{+}+\mathrm{OH}^{-}$(for basic gases)

$\mathrm{HA}+\mathrm{H}_{2} \mathrm{O}=\mathrm{A}^{-}+\mathrm{H}_{3} \mathrm{O}^{+}$(for acidic gases)

with equilibrium constants of

$K_{\mathrm{B}}=a_{\mathrm{BH}^{+}} a_{\mathrm{OH}^{-}} / P_{\mathrm{B}}$

$K_{\mathrm{HA}}=a_{\mathrm{H}^{+}} a_{\mathrm{A}^{-}} / P_{\mathrm{HA}}$

where $P_{\mathrm{B}}$ and $\boldsymbol{P}_{\mathrm{HA}}$ are the partial pressures of the dissolved gases. Therefore, since the $\mathrm{pH}$ of the film in contact with the ion-selective electrode is highly buffered, at equilibrium, $a_{\text {conj.ion }}\left(a_{\mathrm{BH}^{+}}\right.$or $\left.a_{\mathrm{A}^{-}}\right)$in the film is directly proportional to the partial pressure of the analyte gas:

$a_{\mathrm{BH}^{+}}=P_{\mathrm{B}} K_{\mathrm{B}} / a_{\mathrm{OH}^{-}}$

$a_{\mathrm{A}^{-}}=P_{\mathrm{HA}} K_{\mathrm{HA}} / a_{\mathrm{H}^{+}}$

On the other hand, for the $\mathrm{pH}$ electrode halfcell, since $a_{\mathrm{OH}^{-}}=K_{\mathrm{W}} / a_{\mathrm{H}^{+}}$, then the activity of protons in the thin film may be given by the following expressions for the two respective cases;

$a_{\mathrm{H}^{+}}=a_{\mathrm{BH}^{+}} K_{\mathrm{W}} / P_{\mathrm{B}} K_{\mathrm{B}}$

$a_{\mathrm{H}^{+}}=P_{\mathrm{HA}} K_{\mathrm{HA}} / a_{\mathrm{A}}$

However, in the $\mathrm{pH}$ half-cell, $a_{\text {conj.ion }}$ is kept high and relatively constant by using appropriate internal solutions as the thin film electrolyte (e.g., $\mathrm{NH}_{4}^{+}$for $\mathrm{NH}_{3}$ sensing, $\mathrm{HCO}_{3}^{-}$for $\mathrm{CO}_{2}$ sensing). Thus, substituting Eqns. 5 and 6 and Eqns. 7 and 8 into Eqn. 2 and combining all the constant terms together yields the following expression for the overall differential cell potential:

$E_{\text {cell }}=K^{\prime} \pm\left(0.059 / z_{i}+0.59 / 1\right) \log P_{\text {gas }}$

where $z_{i}$ is the charge on the conjugate anion or cation sensed in the half-cell containing the internal buffer solution. As can be seen, such a cell should respond to the partial pressure of the acidic or basic gas with a theoretical slope of $118 \mathrm{mV}$ decade $^{-1}$ if the conjugate acid or base of the detected gas has a charge of \pm 1 . If the charge on the detected ion in half-cell 2 is \pm 2 , then the 


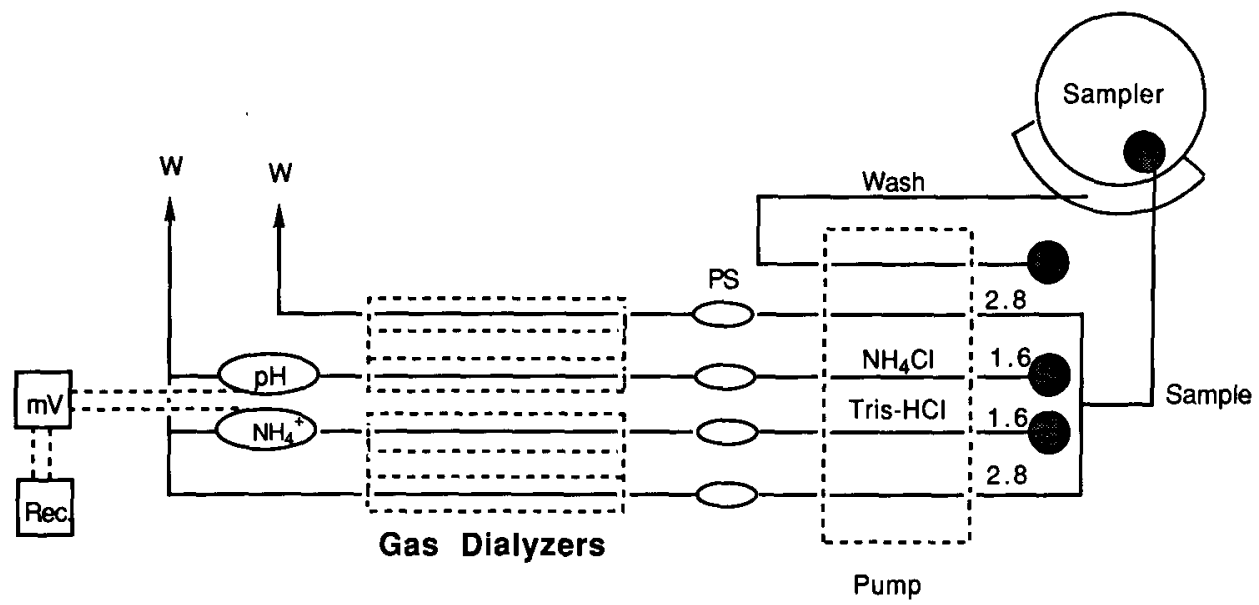

Fig. 2. Schematic diagram of differential flow-through ammonia-N assay system. Rec., recorder, $\mathrm{mV}, \mathrm{pH}-\mathrm{mV} \mathrm{meter} ; \mathrm{pH}$, tubular $\mathrm{pH}$ electrode; $\mathrm{NH}_{4}^{+}$, tubular ammonium electrode; PS, pulse suppressor; W, waste.

theoretical slope would be $89 \mathrm{mV}$ decade $^{-1}$. In practice, such slopes will only be observed over limited concentration ranges of the analyte gas, owing to changes in the ionic composition of the internal electrolyte layers of each half-cell at increasing gas levels [20].

To adapt this type of differential detection scheme to flow-through arrangements (e.g., flowinjection analysis or segmented continuous flow methods), it is convenient to use two gas dialysis chambers in which the sample and recipient solution streams are flowing continuously, and the recipient solutions are allowed to contact each other downstream of the two ion-selective electrode detectors (see Fig. 2). In this case, depending on the exact geometry of the dialyzers used and the flow-rates of the sample and recipient streams, the detection process is most always a non-equi-

TABLE 1

Examples of some analyte gases and the associated half-cell detection chemistries required for the design of static and flow-through differential gas-sensing arrangements with enhanced sensitivities

\begin{tabular}{|c|c|c|c|c|}
\hline $\begin{array}{l}\text { Analyte } \\
\text { gas }\end{array}$ & $\begin{array}{l}\text { Pertinent equilibrium } \\
\text { reactions }\end{array}$ & $\begin{array}{l}\text { Half-cell } 1 \\
\text { (conjugate ion sensed in } \\
\text { buffered internal solution) }\end{array}$ & $\begin{array}{l}\text { Half-cell } 2 \\
\text { (pH-sensing) } \\
\text { electrolyte solution }{ }^{\text {a }}\end{array}$ & $\begin{array}{l}\text { Theoretical } \\
\text { slope } \\
\left(\mathrm{mV} \text { decade }^{-1}\right)\end{array}$ \\
\hline $\mathrm{NH}_{3}$ & $\mathrm{NH}_{3}+\mathrm{H}_{2} \mathrm{O} \rightleftharpoons \mathrm{NH}_{4}^{+}+\mathrm{OH}^{-}$ & $\mathrm{NH}_{4}^{+}[10]^{\mathrm{c}}$ & $\mathrm{NH}_{4} \mathrm{Cl}$ & 118 \\
\hline $\mathrm{CO}_{2}$ & $\begin{array}{l}\mathrm{CO}_{2}+\mathrm{H}_{2} \mathrm{O} \rightleftharpoons \mathrm{HCO}_{3}^{-}+\mathrm{H}^{+} \\
\mathrm{HCO}_{3}^{-} \rightleftharpoons \mathrm{CO}_{3}^{2-}+\mathrm{H}^{+}\end{array}$ & $\begin{array}{l}\mathrm{HCO}_{3}^{-} \\
\mathrm{CO}_{3}^{2-}\end{array}$ & $\begin{array}{l}\mathrm{MHCO}_{3} \\
\mathrm{MHCO}_{3}\end{array}$ & $\begin{array}{r}118 \\
89\end{array}$ \\
\hline $\mathrm{SO}_{2}$ & $\begin{array}{l}\mathrm{SO}_{2}+\mathrm{H}_{2} \mathrm{O} \rightleftharpoons \mathrm{HSO}_{3}^{-}+\mathrm{H}^{+} \\
\mathrm{HSO}_{3}^{-} \rightleftharpoons \mathrm{SO}_{3}^{2-}+\mathrm{H}^{+}\end{array}$ & $\mathrm{SO}_{3}^{2-}[15]$ & $\begin{array}{l}\mathrm{MHSO}_{3} \\
\mathrm{MHSO}_{3}\end{array}$ & $\begin{array}{r}118 \\
89\end{array}$ \\
\hline $\mathrm{NO}_{2}$ & $2 \mathrm{NO}_{2}+\mathrm{H}_{2} \mathrm{O} \rightleftharpoons \mathrm{NO}_{3}^{-}+\mathrm{NO}_{2}^{-}+2 \mathrm{H}^{+}$ & $\begin{array}{l}\mathrm{NO}_{3}^{-}[14] \\
\mathrm{NO}_{2}^{-}[22]\end{array}$ & $\begin{array}{l}\mathrm{MNO}_{2} \\
\mathrm{MNO}_{2}\end{array}$ & $\begin{array}{l}118 \\
118\end{array}$ \\
\hline $\mathrm{H}_{2} \mathrm{~S}$ & $\begin{array}{l}\mathrm{H}_{2} \mathrm{~S}+\mathrm{H}_{2} \mathrm{O} \rightleftharpoons \mathrm{HS}^{-}+\mathrm{H}^{+} \\
\mathrm{HS}^{-} \rightleftharpoons \mathrm{S}^{2-}+\mathrm{H}^{+}\end{array}$ & $\begin{array}{l}\mathrm{HS}^{-} \\
\mathrm{S}^{2-}[23]\end{array}$ & $\begin{array}{l}\text { MHS } \\
\text { MHS }\end{array}$ & $\begin{array}{r}118 \\
89\end{array}$ \\
\hline HF & $\mathrm{HF} \rightleftharpoons \mathrm{F}^{-}+\mathrm{H}^{+}$ & $F^{-}[24]$ & MF & 118 \\
\hline HOAc & $\mathrm{HOAc} \rightleftharpoons \mathrm{AcO}^{-}+\mathrm{H}^{+}$ & $\mathrm{OAc}^{-}$ & MOAc & 118 \\
\hline $\mathrm{Cl}_{2}$ & $\mathrm{Cl}_{2}+\mathrm{H}_{2} \mathrm{O} \rightleftharpoons \mathrm{Cl}^{-}+\mathrm{ClO}^{-}+2 \mathrm{H}^{+}$ & $\mathrm{Cl}^{-}[25]$ & $\mathrm{MCl}$ & 118 \\
\hline
\end{tabular}

${ }^{a} \mathrm{M}$ represents alkali metal ion. ${ }^{b}$ In restricted range governed by concentration of electrolyte used in half-cell 2 and also pH and buffer capacity of internal solution employed in half cell $1 .^{c}$ Reference describing suitable ion-selective membrane electrode to sense conjugate ion. 
librium one [21]. Nonetheless, if the fraction of gas transfer across the gas permeable membrane of each dialyzer is relatively constant with dissolved gas concentration (this is not always the case; see Results and Discussion), then the potentiometric response of the system may still be expressed by Eqn. 11. The non-equilibrium nature of such flow-through measurements will, however, significantly affect the detection limits and dynamic measuring range of these systems when compared with the static sensor configuration.

Table 1 summarizes the internal electrolyte conditions, sensing chemistries and ion-selective membrane electrodes required to adapt the differential method to the detection of various analyte gases. Also listed are the predicted slopes for the resulting sensing configurations. While the use of two polymeric-type ion-selective membrane electrodes (one always being a pH-sensitive electrode) is convenient from cost and fabrication standpoints, in principle other types of ion-selective membranes may be used, including pressed pellet solid-state, single crystal or glass. In some instances, practical implementation of this new approach will require the development of a suitable membrane electrode selective for the conjugate base anion of the respective gas. In others, the required membrane electrode with suitable selectivity has already been described in the literature and an appropriate reference is provided in Table 1. For the purpose of this paper, the ammoniasensing arrangement serves as a convenient model, since the required $\mathrm{NH}_{4}^{+}$-selective membrane can be readily prepared by incorporating the antibiotic nonactin into a plasticized PVC membrane [10].

\section{EXPERIMENTAL}

\section{Apparatus}

All potentiometric measurements were made with a Fisher (Romulus, MI) Accumet Model 620 $\mathrm{pH}-\mathrm{mV}$ meter and recorded on a Houston Instruments (Houston, TX) Omni-Scribe strip-chart recorder. A schematic diagram of the AutoAnalyzer manifold used to evaluate the flow-through differential ammonia gas-sensing system is shown in Fig. 3. The recipient buffer and electrolyte solutions and the sample were pumped through the system with an Ismatec (Zurich) variable-speed peristaltic pump. A Technicon (Tarrytown, NY) Sampler II served as the autosampler, and was operated at a throughput of 30 samples per hour. Two 12-in. Technicon dialyzer blocks fitted with

\section{Gas Dialyzers}
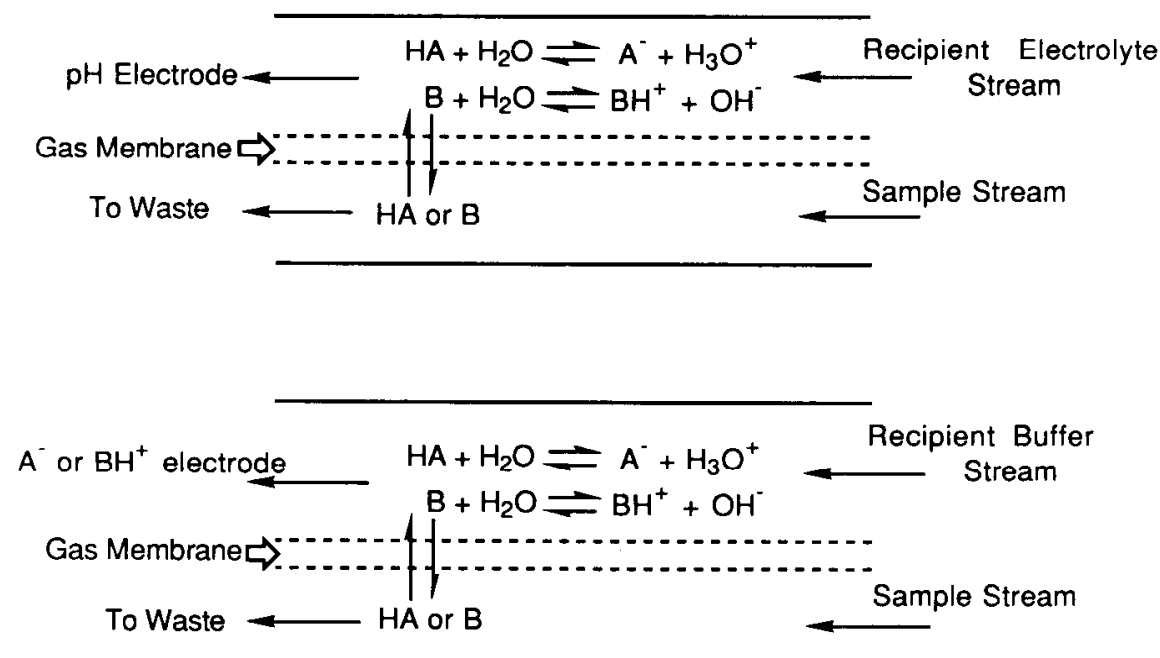

Fig. 3. Expanded view of each gas dialyzer unit and the chemical processes that take place within. 
$0.2-\mu \mathrm{m}$ pore-size PTFE membranes (W.L. Gore, Elkton, MD) served as the gas dialyzers.

\section{Reagents}

All chemicals used were of analytical-reagent grade or better. Standards and buffer solutions were prepared with distilled, deionized water. Nonactin was obtained from Sigma Chemical (St. Louis, MO), poly(vinyl chloride) (PVC), chromatographic grade, from Polysciences (Warringtone, PA), dibutyl sebacate from Eastman Kodak (Rochester, NY) and tridodecylamine (TDDA) and potassium tetrakis ( $p$-chlorophenyl)borate (KTpClPB) from Fluka (Ronkonkoma, NY). Ammonia gas electrode internal filling solution "from Orion (Cambridge, MA) was used as the inner electrolyte of the $\mathrm{pH}$-sensing half-cell in the static sensor design.

\section{Static differential ammonia gas sensor}

The $\mathrm{pH}$ and ammonium ion-selective polymer membranes were prepared as described previously $[9,10]$. After drying, $\mathrm{pH}$ and ammonium ion-selective electrodes were fabricated by cutting a $2-\mathrm{mm}$ diameter of the appropriate membrane and attaching them to the end of disposable plastic pipet tips having small pieces of Tygon tubing ( $2-\mathrm{mm}$ diameter) at the end. Each membrane was sealed to the Tygon tubing with a paste made of tetrahydrofuran (THF), dibutyl sebacate and PVC (that used to cast the membranes except without ionophore). For the $\mathrm{pH}$ electrode, the inside of the plastic tube was filled with $0.05 \mathrm{M}$ phosphate buffer ( $\mathrm{pH} 7.5$ ) containing $0.01 \mathrm{M} \mathrm{NaCl}$. The ammonium-selective membrane electrode was filled with $0.1 \mathrm{M} \mathrm{NH}_{4} \mathrm{Cl}$. The final static differential ammonia gas sensor was constructed as depicted in Fig. 1. The internal $\mathrm{pH}$ and ammonium electrodes were placed in slightly larger plastic pipet tips which had been prefilled with internal gas-sensing solutions [Orion internal filling solution and $0.1 \mathrm{M}$ Tris- $\mathrm{HCl}$ buffer (pH 7.9), respectively]. The end of each pipet was covered by a PTFE gas-permeable membrane $(0.2$ $\mu \mathrm{m}$ pore size) (W.L. Gore). These gas membranes were held in place by a plastic O-ring (see [9-11] for more detailed diagrams of each half-cell assembly). When each internal electrode was pressed into the outer pipet, a thin film of internal buffer or electrolyte formed between the gas membrane and the polymeric ion-selective membrane. Final electrical connections were made via a salt bridge between the bulk internal filling solutions of the two gas-sensing probes. Lithium acetate was specifically used as the salt bridge electrolyte (over sodium and potassium salts) to avoid possible leakage of interfering cations into the internal filling solutions. The PVC-nonactin-based ammonium and the TDDA-based $\mathrm{pH}$ electrodes display minimal response to $\mathrm{Li}^{+}[26,27]$. The response of the two electrode static sensor configuration was evaluated by recording equilibrium potentials of the cell after making standard additions of $\mathrm{NH}_{4} \mathrm{Cl}$ to $50 \mathrm{ml}$ of $0.01 \mathrm{M} \mathrm{NaOH}$.

\section{Flow-through system}

Figure 3 illustrates the continuous-flow manifold used to evaluate the differential flow-through ammonia detector. As shown, the sample stream is split equally so that exactly half of the fluid flows through each gas dialysis chamber. The required tubular flow-through polymer membrane $\mathrm{pH}$ and ammonium ion-selective electrodes were prepared as described previously $[9,12,13]$. A $0.01 \mathrm{M} \mathrm{NH}_{4} \mathrm{Cl}$ solution and a $0.05 \mathrm{M}$ Tris- $\mathrm{HCl}$ buffer ( $\mathrm{pH} 7.5$ ) were used as the recipient stream solutions in the $\mathrm{pH}-$ and ammonium-sensing flow-through halfcells, respectively. The electrochemical circuit was completed when the flows of both recipient streams were merged after the tubular membrane electrode detectors. Standard $\mathrm{NH}_{4} \mathrm{Cl}$ solutions were prepared in $0.01 \mathrm{M} \mathrm{NaOH}$ and placed in the AutoAnalyzer sampler immediately prior to measurement. Recorded peak heights (in $\mathrm{mV}$ ) were used to construct the response curves. The response of the flow system toward various amines was evaluated in a similar manner. The sampling rate for most experiments was $30 \mathrm{~h}^{-1}$ with a sample-to-wash ratio of $1: 2$.

\section{Determination of ammonia in bioreactor media}

The analytical utility of the differential flowthrough system was evaluated by determining the ammonia-nitrogen content of various samples of bioreactor media used to produce monoclonal antibodies. These samples were obtained from the 
University of Michigan's Department of Chemical Engineering. The samples were diluted $1+9$ with $0.01 \mathrm{M} \mathrm{NaOH}$ prior to measurement with the automated system. Aliquots of the same samples were also tested for ammonia- $\mathrm{N}$ content using two conventional methods; an L-glutamate dehydrogenase enzymatic assay procedure [28] and a commercial static Orion Model 95-12 ammonia electrode method [29].

\section{RESULTS AND DISCUSSION}

\section{Static gas sensor configuration}

Figure 4 illustrates the typical equilibrium potentiometric response obtained for the differential static ammonia gas sensor when various concentrations of ammonium chloride are added to a well stirred $0.01 \mathrm{M} \mathrm{NaOH}$ sample solution $(n=3)$. The response time to reach the equilibrium potential varied depending on the concentration of sam-

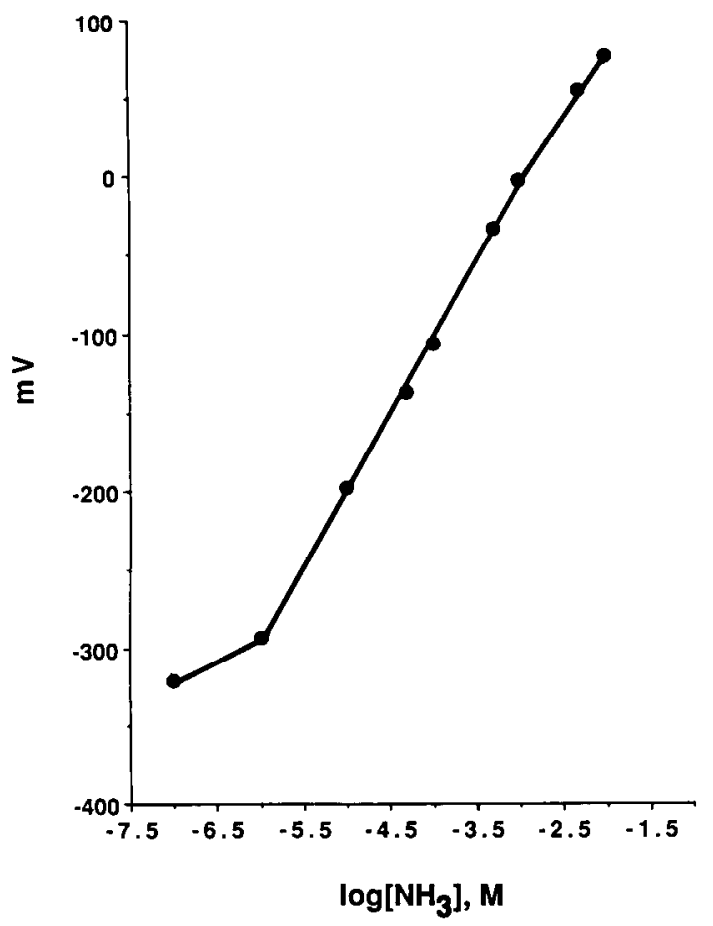

Fig. 4. Typical calibration graph for differential ammonia sensor constructed in accordance with the design shown in Fig. 1. Each point represents an average of three determinations. ple ammonia. At concentrations $>0.5 \mathrm{mM}$ the response times were typically less than $1 \mathrm{~min}$, whereas in the range $1-500 \mu \mathrm{M}$ response times of 2-5 min were observed. These dynamic response properties are similar to those of existing commercial potentiometric ammonia sensors [30] and newer research prototypes previously fabricated with polymeric $\mathrm{pH}$ and ammonium-selective internal electrodes [9-11].

For three separate experiments, the average slope of the static sensor's differential ammonia response was found to be $96.3 \pm 0.5 \mathrm{mV}$ decade $^{-1}$ in the range $10^{-6}-10^{-3} \mathrm{M} \mathrm{NH}_{3}$. This is far greater than the slopes observed for conventional Severinghaus-style sensors (e.g., 55-59 mV decade $^{-1}$ ) or those based on single internal polymeric $\mathrm{pH}$ and ammonium ion detectors $[9,10]$. This slope is, however, less than the theoretical value of $118 \mathrm{mV}$ decade $^{-1}$ predicted using the simplified model considered above. This difference is expected in the case of the static sensor configuration for a number of reasons. First, it has been found that the polymeric $\mathrm{pH}$ and ammonium-selective membranes used in each half-cell typically exhibit sub-Nernstian behavior even when used as independent ion sensors under equilibrium conditions (e.g., slopes range from 54 to $58 \mathrm{mV}$ decade $^{-1}$ ). Second, owing to geometric design limitations [30], it is impossible to isolate completely the thin film of electrolyte and buffer in each half-cell from the internal bulk of these solutions. Thus, at equilibrium, a steady-state exchange of bulk solution with the thin film causes the overall response (i.e., change in thin-film $a_{\mathrm{H}^{+}}$ in half-cell 1 and thin-film $a_{\mathrm{NH}_{4}^{+}}$in half-cell 2) to be less than expected for a truly closed thin-film reaction layer $[20,30]$. Finally, it has been shown previously that the response slopes for gas sensing half-cells based on conjugate ion detection, in this case ammonium ions, are highly dependent on the $\mathrm{pH}, \mathrm{p} K_{\mathrm{a}}$ and the ionic strength of the buffer solution used as the internal solution for the sensor [20]. While the $0.1 \mathrm{M}$ Tris- $\mathrm{HCl}$ buffer used here should provide a reasonably strong buffer capacity, at sample ammonia levels $>10^{-3} \mathrm{M}$ there will nonetheless be a significant $\mathrm{pH}$ change within the thin-film buffer layer that will cause a dramatic decrease in the observed slope (see [20] for details). 
In practice, this limits the range in which the observed potentiometric signal is linearly related to the logarithm of ammonia concentration in the sample (in this case, ca. $10^{-3} \mathrm{M}$; see Fig. 4).

The detection limits of the combined differential ammonia sensor will also depend on the detection limits of each individual gas sensing half-cell. Indeed, despite the significant enhancement in slope over a given concentration range of dissolved ammonia, the absolute detection limits of the static differential design $\left(6 \times 10^{-7} \mathrm{M} \mathrm{NH}_{3}\right)$, as determined by the IUPAC recommended method [31], do not differ significantly from those observed when each half-cell is employed in a conventional single working electrode ammonia probe $[9,10]$. Since it has been found previously that the detection limits for ammonia arc better when a single working electrode-type sensor is fabricated using the ammonium ion electrode as the inner transducer [10], it is likely that the ammonia response in this half-cell dictates the absolute lower limit of response of the differential design. The precision of the static differential ammonia sensor at higher concentrations is better than that of a single working electrode type of sensor owing to the enhanced sensitivity $(98 \pm 0.5$ $\mathrm{mV}$ decade $^{-1}, n=3$, over a range from $1 \times 10^{-5}$ to $1 \times 10^{-3} \mathrm{M}$ ammonia). Indeed, variations in the absolute potentials at given analyte concentrations ranged from $\pm 1.7 \mathrm{mV}$ at $1 \times 10^{-5} \mathrm{M}$ to $\pm 1.1 \mathrm{mV}$ at $1 \times 10^{-3} \mathrm{M}$ (s.d. for $n=3$ ). Given the enhanced slope, at millimolar levels of ammonia the observed reproducibility corresponds to a precision of $2.6 \%$ with respect to measured ammonia concentration values.

\section{Flow-through differential ammonia gas-sensing system}

To adapt the differential detection scheme to a flow-through measurement arrangement, the concept of using gas dialysis in conjunction with flowing recipient solutions and tubular flowthrough ion-selective electrode detectors was employed (see Figs. 2 and 3). Each of the respective flow-through half-cell gas detectors had been evaluated independently in previous work with a single gas dialyzer unit $[9,12,13]$; however, as shown in Fig. 3, for differential sensing the sample stream must be split so that equal fractions pass through two gas dialysis detection units simultaneously. Figure 5 illustrates the typical ammonia calibration graph obtained for this flow-through arrangement. In contrast to the static system, a nearly theoretical slope value of $118 \mathrm{mV}$ decade $^{-1}$ in the range $2 \times 10^{-5}-10^{-3} \mathrm{M}$ is observed. This enhanced slope, relative to the static arrangement, may be attributed to fact that the detection process is not at equilibrium. That is, given the flowrates and relative sample to recipient stream volumes in the dialysis chambers used here $(1: 1)$, only a fraction of the total ammonia in the sample stream actually enters the flowing recipient buffer and electrolyte streams during the time the sample spends in two dialysis chambers. Hence the geometric cffects, and changes in the ionic composition/ $\mathrm{pH}$ of the electrolyte and buffer solutions

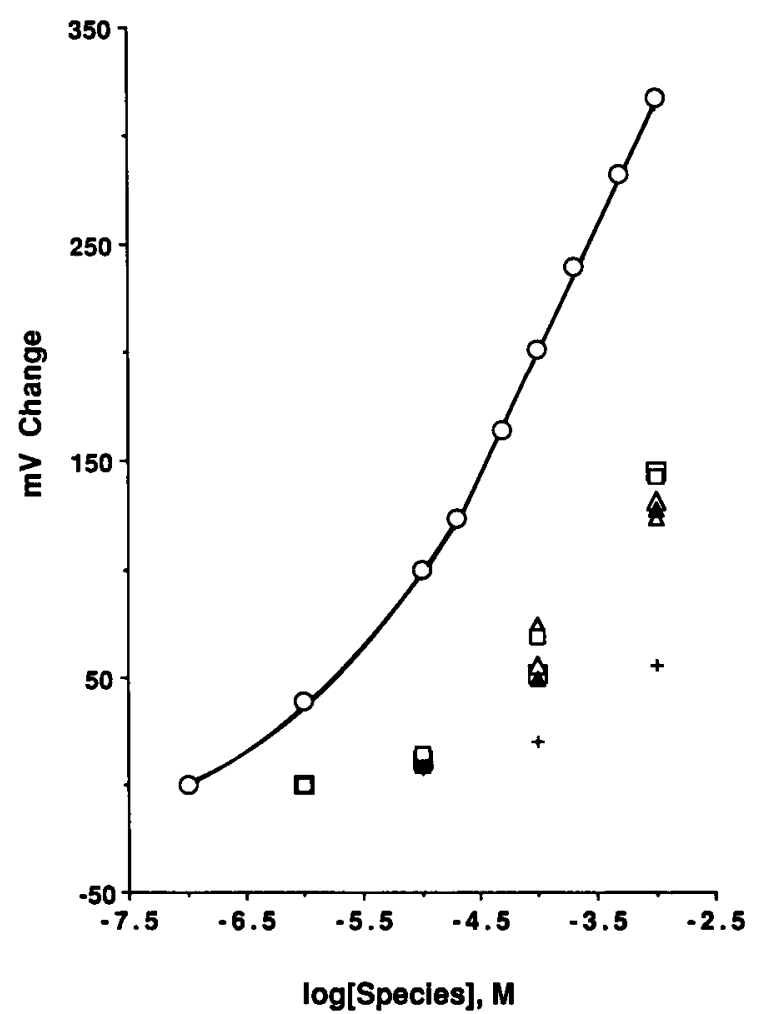

Fig. 5. Response of the differential flow-through ammonia-N detector to $(O)$ ammonia and various amine species: ( $\square$, large) ethylamine; ( $\Delta$, small) diethylamine; ( $\Delta$, large) methylamine; (ム) butylamine; (+) ethanolamine; ( $\square$, small) dimethylamine. 
that influence the observed slopes in the equilibrium static sensing configuration, are not major factors in the response characteristics of the flowthrough design. However, given the fact that both flow-through membrane electrode detectors actually exhibit slightly sub-Nernstian properties in direct response to protons and ammonium ions (e.g., 54-58 $\mathrm{mV}$ decade $^{-1}$; thereby yielding a maximum slope for differential sensing of 108-116 $\mathrm{mV}$ decade $^{-1}$ ), the observed theoretically predicted slope for the differential flow-through ammonia detection must be due to the fact that one or both of the half-cell detectors operates in a mode where the fraction of sample ammonia gas transferred across the gas permeable membrane increases slightly as a function of sample ammonia concentration. This behavior has been observed previously with both the $\mathrm{pH}$ - and ammonium ion electrode-based half-cell flow-through ammonia detectors when used independently $[9,12,13]$ and accounts, in part, for the observed behavior of the differential flow-through system.

As with any continuous-flow analysis system, for low-level measurements optimum reproducibility can be achieved only when sample solutions have ammonia levels within a restricted concentration range (1-2 decades). For example, Fig. 6 shows the typical strip-chart recording obtained for multiple ammonia standards in the range $10^{-5}-10^{-3}$ M. A similar response is observed when the standards are run in descending concentrations. For measurements made in this range, peak potentials are reproducible to $\leqslant \pm 1 \mathrm{mV}$ (s.d. for six measurements at each concentration). Considering the enhanced slope of the differential detector, this level of precision corresponds to an r.s.d. of $\leqslant 2 \%$ for unknown concentration determinations. This precision is better than that obtained previously when each of the two half-cells was employed separately in the design of flowthrough ammonia detectors (e.g., r.s.d. 4\%) [9,12]. The detection limit of the combined differential ammonia sensor arrangement is ca. $5 \times 10^{-7} \mathrm{M}$ under the conditions outlined under Experimental. Naturally, this lower limit is dependent on the flow-rates of both the sample and recipient streams. The detection limit of the differential flow-through system is governed by the gas-sens-

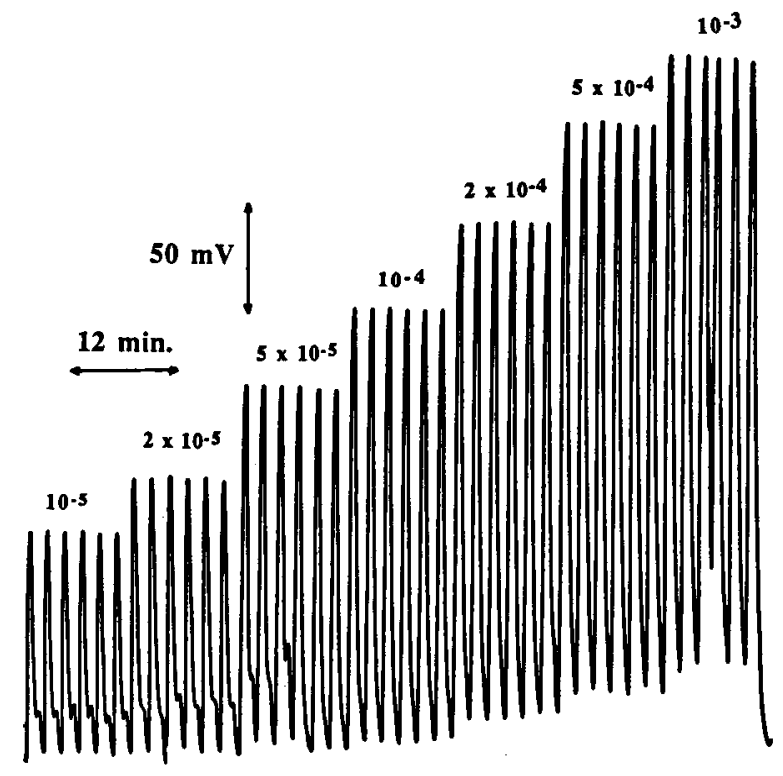

Fig. 6. Typical strip-chart recording obtained for differential flow-through ammonia- $\mathbf{N}$ system. Concentrations are in $\mathbf{M}$. Conditions: sample-to-wash ratio, $1: 2$; sampling rate, $30 \mathrm{~h}^{-1}$.

ing half-cell that exhibits the lower detection limit (e.g., $\mathrm{NH}_{4}^{+}$-based half-cell in these studies).

It is known that static and flow-through ammonia detectors that employ $\mathrm{pH}$ electrodes as inner sensing elements display large responses to volatile amines $[32,33]$. The amines diffuse through the microporous membrane of the static sensor or flow-through gas dialyzer and alter the $\mathrm{pH}$ of the internal or recipient stream $\mathrm{NH}_{4} \mathrm{Cl}$ solution. It is also known that both static or flow-through detectors that are fabricated with inner ammonium ion-selective electrodes in conjunction with internal recipient buffers provide a dramatic enhancement in the selectivity over the amines [13,33]. Thus, for any differential arrangement using these two modes of detection simultaneously, it is likely that the selectivity of the resultant system would be somewhere in between. As shown in Fig. 5, this is in fact the case for the new differential flowthrough ammonia detection configuration. Most of the potentiometric response to the various amines arises from the $\mathrm{pH}$ half-cell [13]. Consequently, enhanced gas sensitivity is obtained at the expense of selectivity, at least when comparing the new differential approach with the previous flow- 


\section{TABLE 2}

Comparison of the results obtained for the determination of ammonia- $\mathrm{N}$ in media samples from bioreactors by a manual commercial Orion ammonia gas sensor, an enzymatic method and the proposed differential flow-through ammonia detector ${ }^{\mathbf{a}, \mathbf{b}}$

\begin{tabular}{rlll}
\hline Sample & $\begin{array}{l}\text { Method } \\
\text { Manual Orion }\end{array}$ & $\begin{array}{l}\text { Differential } \\
(\mathrm{mM})\end{array}$ & $\begin{array}{l}\text { Enzymatic }^{\mathrm{d}} \\
(\mathrm{mM})\end{array}$ \\
\cline { 2 - 4 } & $(\mathrm{mM})$ & 2.20 & 2.72 \\
1 & 2.31 & 0.80 & 0.93 \\
2 & 0.89 & 2.50 & 2.59 \\
3 & 2.31 & 3.73 & 3.23 \\
4 & 3.64 & 0.88 & 1.06 \\
5 & 0.92 & 1.91 & 1.83 \\
6 & 1.76 & 2.49 & 2.47 \\
7 & 2.53 & 2.25 & 2.46 \\
8 & 2.31 & 3.42 & 3.81 \\
9 & 3.49 & 0.90 & 1.04 \\
10 & 0.89 & 1.78 & 1.98 \\
11 & 1.71 & 0.81 & 0.83 \\
12 & 0.89 & 2.35 & 2.52 \\
13 & 2.31 & 2.40 & 2.39 \\
14 & 2.35 & 0.97 & 1.24 \\
15 & 0.91 & 1.22 & 1.37 \\
16 & 1.10 & 2.63 & 2.66 \\
17 & 2.57 & 1.27 & 1.44 \\
18 & 1.07 & 2.53 & 2.72 \\
19 & 2.42 & 3.14 & 3.81 \\
20 & 3.48 & 0.85 & 0.83 \\
21 & 0.94 & 1.86 & 2.05 \\
22 & 1.99 & & \\
\hline
\end{tabular}

a Average difference (differential - manual Orion) $=0.10$, s.d. $=0.07$, differences range $=0.01-0.34$. Average difference (differential - enzymatic) $=0.20$, s.d. $=0.18$, differences range $=0.02-0.67{ }^{\mathrm{b}}$ Differential $=0.974$ (Orion) +0.056 ; standard error of slope $=0.030$; standard error of $y$ (est.) $=0.126 ; r=$ 0.981 . Differential $=0.945$ (enzymatic) -0.026 ; standard error of slope $=0.054$; standard error of $y$ (est.) $=0.227 ; r=0.938$. ${ }^{c}$ Average of three determinations. ${ }^{d}$ Average of two determinations.

through detector prepared with only the ammonium ion-sensing half-cell [12,33].

To demonstrate the analytical utility of the new differential flow-through ammonia detector, the proposed system was used to determine the ammonia- $\mathrm{N}$ content (total dissolved ammonia gas plus ammonium ions) of media samples taken from bioreactors used to produce monoclonal antibodies. It is known that elevated levels of ammonia- $\mathrm{N}$ in such culture media can inhibit hybridoma cell growth [34]. Ammonia-N values ob- tained via the differential flow-through ammonia detector correlated well with the results given by both a manual commercial ammonia electrode procedure and an enzymatic method (see Table 2 ).

\section{Conclusions}

As indicated in Table 1, the concept of differential gas sensing should be applicable to the detection of analytes other than ammonia. For example, it should be possible to design an $\mathrm{SO}_{2}-$ sensitive differential cell with enhanced gas sensitivity by detecting hydrogensulfite/sulfite from diffusing $\mathrm{SO}_{2}$ in one half cell \{using the new $\mathrm{Hg}$ (II)-based polymer membrane [15]\} and a $\mathrm{pH}$ change in the other. Similarly, detectors for $\mathrm{NO}_{2}$ could be devised by employing either a nitrate- or a nitrite-selective membrane clectrode in conjunction with an appropriate internal or flowing recipient buffer reagent in one half-cell and nitrite solutions with a $\mathrm{pH}$ sensor in the other. In all instances a significant enhancement in the response slope compared with existing gas-sensing arrangements should be realized. However, as with the ammonia configurations described above, ultimately the selectivity of these systems will probably be limited by the sensitivity of the $\mathrm{pH}$ sensor-based half-cell to other acidic or basic gases. Nonetheless, in instances where decreasing the uncertainty in a measured gas concentration is desirable, and where interferences from other gases would be minimal, the use of differential potentiometric gas-sensing schemes may prove to be an attractive alternative to existing measurement methods.

This work was supported in part by grants from the National Science Foundation (EET8712756) and the National Institutes for Health (GM-28882).

\section{REFERENCES}

1 R.L. Solsky, Anal. Chem., 60 (1988) 106R.

2 M. Riley, in A.K. Covington (Ed.), Ion-Selective Electrode Methodology, Vol. II, CRC Press, Boca Raton, 1979, Chap. 1.

3 Ilandbook of Electrodc Tcchnology, Orion Research, Cambridge, MA, 1982. 
4 B.A. Shapiro, R.A. Harrison and J.R. Waton, Clinical Applications of Blood Gases, Year Book Medical Publishers, Chicago, 1982.

5 G.A. Rechnitz, Science, 214 (1981) 287.

6 G.G. Guilbault, Analytical Uses of Immobilized Enzymes, Marcel Dekker, New York, 1984, p. 112.

7 I. Karube and S. Suzuki, Ion-Sel. Electrode Rev., 6 (1984) 15.

8 J.W. Severinghaus and A.F. Bradley, J. Appl. Physiol., 13 (1958) 515.

9 W.N. Opdycke, S.J. Parks and M.E. Meyerhoff, Anal. Chim. Acta, 155 (1983) 11.

10 M.E. Meyerhoff, Anal. Chem., 52 (1980) 1532.

11 K.H. Robins and M.E. Meyerhoff, Anal. Chem., 52 (1980) 2383.

12 Y.M. Fraticelli and M.E. Meyerhoff, Anal. Chem., 53 (1981) 992.

13 H.L. Lee and M.E. Meyerhoff, Analyst, 110 (1985) 371.

14 G.B. Martin and M.E. Meyerhoff, Anal. Chim. Acta, 186 (1986) 71.

15 D.M. Pranitis and M.E. Meyerhoff, Anal. Chim. Acta, 217 (1989) 123.

16 J.A. Greenberg and M.E. Meyerhoff, Anal. Chim. Acta, 141 (1982) 57.

17 M.E. Meyerhoff, D.M. Pranitis, H.S. Yim, N.A. Chaniotakis and S.B. Park, Chemical Sensors and Microinstrumentation (ACS Symp. Ser. 403), American Chemical Society, Washington, DC, 1989, p. 26.

18 R. Stepak, Fresenius' Z. Anal. Chem., 315 (1983) 629.
19 G.S. Cha and M.E. Meyerhoff, Electroanalysis, 1 (1989) 205.

20 M.E. Meyerhoff, Y.M. Fraticelli, W.N. Opdycke, L.G. Bachas and A.D. Gordus, Anal. Chim. Acta, 154 (1983) 17.

21 W.E. van der Linden, Anal. Chim. Acta, 151 (1983) 359.

22 P. Schulthess, D. Ammann, B. Krautler, C. Caderas, R. Stepanek and W. Simon, Anal. Chem., 57 (1985) 1397.

23 S.E. Schmitt and E. Pungor, Anal. Lett., 4 (1971) 641.

24 M.S. Frant and J. Ross, Science, 154 (1966) 1553.

25 K. Hartman, S. Luterotti, H.F. Ossward, P.C. Meier, M. Oehme, D. Ammann and W. Simon, Mikrochim. Acta, Part II, (1978) 235.

26 S.C. Ma, N.A. Chaniotakis and M.E. Meyerhoff, Anal. Chem., 60 (1988) 2293.

27 U. Oesch, Z. Brzozka, A. Xu and W. Simon, Anal. Chem., 58 (1986) 2285.

28 P.J. Buttery, Anal. Biochem., 47 (1972) 294.

29 S.S. Ozturk, M.E. Meyerhoff and P.O. Palsson, Biotechnol. Tech., 3 (1989) 217.

30 J.W. Ross, J.H. Riseman and J.A. Krueger, Pure Appl. Chem., 36 (1973) 473.

31 IUPAC, Pure Appl. Chem., 48 (1976) 129.

32 M.E. Lopez and G.A. Rechnitz, Anal. Chem., 54 (1982) 2085.

33 Y.M. Fraticelli and M.E. Meyerhoff, Anal. Chem., 53 (1981) 1857.

34 M.W. Glacken, R.J. Fleischaker and A.J. Sinskey, Biotechnol. Bioeng., 28 (1986) 1676. 